\title{
Komik Pendidikan Berorientasi Children Learning in Science Pada Muatan IPA di Sekolah Dasar
}

\author{
I Gede Ananda Sedana Putra ${ }^{1 *}$, DB. Kt. Ngurah Semara Putra \\ ${ }^{1}$ Prodi Pendidikan Guru Sekolah Dasar, Universitas Pendidikan Ganesha, \\ Singaraja, Indonesia, \\ *e-mail: sedanachasterix@gmail.com
}

\begin{abstract}
Abstrak
Penelitian pengembangn media pembelajaran komik pendidikan dilatarbelakangi oleh kurangnya penggunaan media pembelajaran khusus komik pendidikan di SD. Hal ini menyebabkan siswa kurang tertarik terhadap materi dalam buku teks dan sulit memahami materi tersebut. Penelitian ini bertujuan untuk mengembangkan komik pendidikan berorientasi children learning in science pada muatan IPA kelas IV SD. Penelitian ini merupakan penelitian pengembangan yang menggunakan model Borg \& Gall yang terdiri dari empat tahapan yaitu tahap pengumpulan informasi, tahap perencanaan, tahap pengembangan produk, dan tahap validasi dan uji coba. Teknik pengumpulan data pada penelitian ini melalui observasi, wawancara, dan kuisioner. Data yang diperoleh dianalisis menggunakan teknik analisis data deskriptif kualitatif dan kuantitatif. Subjek yang terlibat dalam pengembangan komik adalah 3 orang ahli, 3 siswa pada tahap uji perorangan, dan 9 siswa pada tahap uji kelompok kecil. Hasil pengujian menunjukkan bahwa validitas aspek isi komik sebesar $92,3 \%$ (sangat baik), validitas aspek desain 94,2\% (sangat baik, validitas aspek media 95,5\% (sangat baik). Hasil uji perorangan dan kelompok kecil diperoleh 91,7\% (sangat baik) dan 91,3\% (sangat baik). Dengan demikian komik pendidikan berorientasi children learning in science dinilai sangat valid dan sangat layak untuk digunakan dalam pembelajaran muatan IPA di kelas IV SD.
\end{abstract}

Kata kunci: komik, children learning in science, IPA

\begin{abstract}
Research on the development of educational comics learning media is motivated by the lack of use of learning media used by Elementary teachers. So, the students had difficulty understanding the material and tend to feel bored. This study aims to developed design of educational comics learning media oriented towards children learning in science in the fourth-grade of elementary school. This research is development research using the Borg \& Gall model which consists of four stages, namely the information gathering stage, the planning stage, the product development stage, and the validation and testing stages. Data collection techniques in this study through observation, interviews, questionnaire, and literature study. The data were analyzed using descriptive qualitative data analysis techniques and quantitative data analysis techniques. The instrument used in this study was a questionnaire. Then the test was carried out by content experts, learning design experts, and instructional media experts. After the validity test, the expert team continued with product testing on research subjects involving 3 students as individual tests and 9 students as small group tests. From the validation tested by subject content experts with an average percentage of $92.3 \%$ in the very good category. The results of the learning design expert test with an average percentage of $94.2 \%$. The results of validation testing by instructional media experts with an average percentage of $95.5 \%$. The individual test results with an average score of $91.7 \%$, and from the test to the small group test reached an average percentage of $91.3 \%$. So it could be stated that the educational comic media with the orientation of children learning in science is very suitable and very feasible to be used in learning science content in fourth-grade elementary school.
\end{abstract}

Keywords: comic, borg \&gall, science 


\section{Pendahuluan}

Kegiatan pembelajaran dapat dinyatakan berhasil bila siswa berhasil memahami materi pembelajaran. Motivasi belajar siswa sangat mempengaruhi kebiasaan dalam kegiatan pembelajaran dan pengerjaan tugas di kelas, sama seperti pernyataan Clayton et.al (dalam Budiarti \& Haryanto, 2016) bahwa "Learner"s motivation has been consistently linked to successful learning." yang artinya Motivasi siswa secara konsisten sangat terkait dengan keberhasilan pembelajaran. Motivasi tidak hanya memiliki peran penting dalam mengupayakan siswa untuk teribat dalam kegiatan akademik. Motivasi merupakan suatu keadaan dalam diri siswa yang mendorong dan mengarahkan perilakunya kepada tujuan yang ingin dicapainya dalam mengikuti pendidikan. Jadi motivasi dalam belajar merupakan suatu daya untuk menggerakkan aktivitas siswa dalam pembelajaran berlangsung sekaligus mengarahkannya untuk mencapai tujuan dari pembelajaran. Maka peranan guru dalam kegiatan pembelajaran siswa yakni sebagai fasilitator dan mediator. Dari sinilah terjadinya pergeseran paradigma yang dimana kegiatan pembelajaran yang bersifat berpusat pada guru (teacher centered) kemudian menjadi bersifat berpusat pada siswa (student centered) (Pramadi et al., 2013). Guru di tuntut agar dapat membuat siswa termotivasi sehingga aktif dalam kegiatan pembelajaran, sebagai fasilitator guru dapat memanfaatkan media pembelajaran seperti alat peraga, tayangan video, atau gambar sebagai media pembelajaran. Media pembelajaran mampu membuat proses pembelajaran akan lebih menarik siswa, sehingga dapat menumbuhkan motivasi belajar yang pada akhirnya dapat meningkatkan hasil belajar siswa (Sudjana \& Rivai, 2011).

Media pembelajaran yang umum digunakan berupa buku teks atau modul yang memiliki ciri khas dengan banyaknya tulisan atau penjelasan dengan kalimat dengan disertai sedikitnya gambar, yang akan cenderung membuat siswa merasa bosan dan kurang termotivasi. Siswa cenderung tidak menyukai buku teks terlebih lagi bila tidak disertai dengan gambar dan ilustrasi yang menarik, dan secara empirik siswa cenderung menyukai buku bergambar yang penuh dengan warna, dan divisualisasikan dalam bentuk realistis atau kartun (Daryanto, 2013). Berdasarkan hasil observasi dan wawancara dengan guru di SD Negeri 1 Kesiman menunjukkan bahwa proses pembelajaran khususnya materi muatan IPA pada kelas IV cenderung monoton dengan menggunakan media konvensional, buku teks, disertai dengan metode ceramah. Hal ini membuat minat siswa menurun sehingga kurang tertarik dalam mengikuti pembelajaran, siswa akan merasa bosan dan tidak memperhatikan materi pelajaran yang disampaikan oleh guru serta menjadi malas untuk belajar. Oleh sebab itu proses pembelajaran menjadi tidak efisien dan efektif. Disinilah guru memanfaatkan perkembangan teknologi dalam bidang IPTEK untuk membuat suatu media pembelajaran yang menarik dan dapat membantu siswa dalam memahami materi yang diajarkan. Maka media yang dikembangkan disini merupakan Komik pendidikan. Komik dipilih karena memiliki beberapa kelebihan yaitu : 1) peranan pokok dari buku komik dalam instruksional adalah kemampuannya dalam menciptakan minat dari siswa, 2) membimbing minat baca yang menarik bagi siswa, 3) melalui bimbingan dari guru, komik dapat berfungsi sebagai penghubung untuk menumbuhkan minat baca, 4) komik dapat menambah perbendaharaan kata-kata pembacanya, 5) mempermudah siswa menangkap hal-hal atau rumusan yang abstrak, 6) dapat mengembangkan minat baca siswa dan salah satu bidang studi yang lain, 7) seluruh jalan cerita komik menuju pada satu hal yakni kebaikan atau studi yang lain (Andriyani \& Kusmariyatni, 2019). Salah satu mata pelajaran yang memerlukan komik pendidikan adalah IPA.

Imu pengetahuan alam (IPA) dikembangkan sebagai pelajaran integrative science dan bukan sebagai pendidikan disiplin ilmu. IPA mengarah pada aplikatif, pada pengembangan kemampuan belajar, kemampuan berpikir, rasa ingin tahu, dan pengembangan sikap peduli, serta dapat bertanggung jawab terhadap lingkungan baik pada lingkungan sosial dan lingkungan alam (Puspitorini et al., 2014). Dengan kata lain, pembelajaran IPA merupakan pembelajaran yang membelajarkan pengetahuan, sikap, 
moral, karakter, dan keterampilan yang diajarkan secara terpadu Salah satu muatan pelajaran yang diajarkan untuk anak Sekolah Dasar adalah IImu IPA. Pada muatan IPA ini mempelajari tentang lingkungan alam sekitar yang mana salah satu materinya adalah metamorphosis (Mifta \& Nurizzati, 2017). Metamorfosis juga disebut dengan daur hidup makhluk hidup merupakan salah satu pelajaran yang diajarkan kepada anak kelas tinggi yakni pada anak kelas 4 (empat) pada tema 6. Siswa diminta agar dapat mengetahui apa itu metamorphosis dan mampu mendeskribsikan daur hidup beberapa hewan di lingkungan sekitarnya seperti kupu-kupu dan jangkrik lebih kompleks. Semakin kompleksnya materi pada pembelajaran IPA maka akan semakin menuntut guru untuk mampu mengemas materi pembelajaran dengan baik dan mampu menyampaikan materi dengan jelas serta menarik agar materi dapat dipahami secara menyeluruh dan optimal oleh peserta didik, sehingga mendapatkan hasil belajar yang maksimal (Martina et al., 2018). Salah satu faktor yang dapat menentukan keberhasilan suatu proses pembelajaran adalah penggunaan media pembelajaran. Model pembelajaran Children Learning In Science (CLIS) dapat diterapkan dalam media pembelajaran komik pendidikan agar terciptanya lingkungan belajar berpikir dalam sains.

Children Learning In Science (anak-anak belajar dalam IPA) merupakan salah satu model pembelajaran dalam IPA yang dilandasi dalam pandangan konstruktivisme dengan memperhatikan serta mempertimbangkan pengetahuan awal peserta didik. Samatoa (dalam Astiti et al., 2017) mengemukakan bahwa rangkaian fase pembelajaran pada model Children Learning In Science diberi nama general structure of a constructivist teaching sequence. Model ini tanpa sadar dapat membantu peserta didik untuk merubah konsepsi awal peserta didik yang salah menuju konsepsi yang benar dengan melewati pembelajaran yang bermakna. Dengan menerapkan model pembelajaran Children Learning In Science (CLIS) akan memberikan kesempatan kepada siswa untuk bebas berpendapat dan bisa selalu berinteraksi dengan lingkungan, karena proses pembelajaran berpusat pada siswa sehingga siswa bisa aktif dan kreatif dalam mengikuti pembelajaran (Surya \& Dantes, 2019).

Penelitian ini penting dilaksanakan untuk membantu membangkitkan kembali motivasi peserta didik dalam pembelajaran sehingga siswa dapat aktif dalam kegiatan pembelajaran berlangsung serta peserta didik dapat merasakan pengalaman belajar yang berkaitan dalam kehidupan sehari hari. Pengembangan komik pendidikan sebagai media pembelajaran mengadopsi teori Children Learning In Science yang diharapkan dapat meningkatkan motivasi belajar siswa. Tujuan yang ingin dicapai dalam penelitian ini adalah menguji validitas dan kelayakan media pembelajaran Komik Pendidikan Berorientasi Children Learning In Science pada muatan IPA Siswa Kelas IV SD dari aspek isi, media, dan desain pembelajaran.

\section{Metode}

Penelitian ini merupakan penelitian pengembangan yang menggunakan model penelitian $\mathrm{R}$ \& $\mathrm{D}$ (Research and Development) yang terdiri atas sepuluh langkah pelaksanaan sebagai berikut: (1) Penelitian dan pengumpulan informasi, (2) Perencanaan, (3) Mengembangkan bentuk pendahuluan produk, (4) Uji lapangan pendahuluan/persiapan, (5) Revisi berdasarkan hasil uji lapangan pendahuluan, (6) Uji lapangan utama, (7) Revisi berdasarkan uji lapangan utama, (8) Uji lapangan operasional, (9) Revisi berdasarkan uji lapangan operasional, (10) Penyebaran dan implementasi. Penerapan langkah-langkah pengembangannya disesuaikan dengan kebutuhan peneliti. Mengingat keterbatasan waktu serta kendala karena situasi di saat pandemic karena covid-19 yang terjadi disaat ini, maka langkah-langkah tersebut disederhanakan menjadi empat langkah pengembangan. Langkah pengembangan yang dilakukan oleh peneliti adalah: (1) Tahap pengumpulan informasi. (2) Tahap perencanaan. (3) Tahap pengembangan produk. (4) Tahap validasi dan uji coba.

Penelitan pengembangan media komik pendidian berorientasi Children Learning In Science dilaksanakan di SD Negeri 1 Kesiman. Subjek uji dalam penelitian ini melibatkan 
3 orang ahli, 3 orang untuk uji perorangan dan 9 orang sebagai uji kelampok kecil. Pada subjek uji coba perorangan, ketiga peserta didik tersebut terdiri dari satu peserta didik yang memiliki hasil belajar tinggi, satu peserta didik yang memiliki hasil belajar sedang, dan satu peserta didik yang memiliki hasil belajar rendah. Hasil belajar peserta didik tersebut dilihat dari hasil nilai semester dan raport peserta didik tersebut. Kemudian pada uji kelompok kecil kesembilan peserta didik dipilih dari hasil belajar yang dilihat dari hasil nilai semester dan raport peserta didik, tiga peserta didik yang memiliki hasil belajar tinggi, tiga peserta didik yang memiliki hasil belajar sedang, dan tiga peserta didik yang memiliki hasil belajar rendah.

Penelitian Pengembangan ini menggunakan empat metode pengumpulan data untuk menjawab permasalahan mengenai proses pengembangan media komik pendidikan yaitu, melalui metode observasi, wawancara, kuisioner atau angket, dan studi pustaka. Dalam penelitian pengembangan ini digunakan dua teknik analisis data, yaitu (1) Metode analisis deskriptif kualitatif adalah suatu cara analisis data dengan cara menyusun secara sistematis dalam bentuk kalimat sehingga memperoleh kesimpulan umum (Agung, 2014). (2) Metode analisis deskriptif kuantitatif ialah suatu cara pengolahan data yang dilakukan dengan jalan menyusun secara sistematis dalam bentuk angka-angka tentang suatu objek sehingga diperoleh kesimpulan umum (Agung, 2014). Metode observasi digunkan untuk mengumpulkan data secara langsung dengan turun ke lapangan untuk memperhatikan guru secara langsung dalam mengajar secara online serta mengamati ketersediaan suatu fasilitas yang dapat mendukung proses pembelajaran dengan baik. Metode wawancara digunakan untuk memperoleh informasi pendukung dari data awal saat observasi sebagai bahan dasar yang dianalisis untuk pengembangan media pembelajaran komik pendidikan serta mendapatkan informasi dari sudut pandang guru kelas. Metode studi pustaka digunakan untuk mendapatkan data/informasi dengan cara mengumpulkan berbagai macam dokumen yang ada terkait dengan tujuan sebagai sarana pendukung lainnya serta melakukan pencatatan secara sistematis. Angket digunakan untuk menguji validitas dan kelayakan komik pendidikan. Angket yang digunakan untuk mendapatkan penilain dari para ahli akan memberikan skor penilaian yang akan dihitung menggunakan rumus berikut.

$$
\mathrm{P}=\frac{\sum(\text { jawaban } \times \text { bobot tiap pilihan })}{n \times \text { bobot terting gi }} \times 100 \%
$$

(Tegeh \& Kirna, 2010:101)

Keterangan :

$$
\begin{array}{ll}
\mathrm{P} & =\text { Persentase Skor } \\
\sum_{\mathrm{N}} & =\text { Jumlah keseluruhan item target } \\
& =\text { Jumlah keseluruhan skor ideal dalam satu item }
\end{array}
$$

Tabel 1. Konversi Tingkat Pencapaian dengan Skala 5

\begin{tabular}{lll} 
Persentase Penguasaan & Kualifikasi & Keterangan \\
\hline $90-100 \%$ & Sangat Baik & Tidak perlu direvisi \\
$75-89 \%$ & Baik & Sedikit direvisi \\
$65-74 \%$ & Cukup & Direvisi secukupnya \\
$55-64 \%$ & Kurang & Banyak hal yang direvisi \\
$00-54 \%$ & Sangat Kurang & Diulangi membuat produk
\end{tabular}

Tabel 2. Metode Analisis Data

\begin{tabular}{lllll}
\hline NO Jenis Data & Sifat Data & $\begin{array}{l}\text { Sumber } \\
\text { Data }\end{array}$ & Teknik Analisis Data \\
\hline $1 \quad \begin{array}{l}\text { Data hasil review ahli isi Kualitatif } \\
\text { bidang studi, data hasil dan } \\
\text { review ahli desain kuantitatif } \\
\text { pembelajaran, dan data }\end{array}$ & $\begin{array}{l}\text { Kuesioner/ } \\
\text { angket }\end{array}$ & $\begin{array}{l}\text { Analisis deskriptif } \\
\text { kualitatif dan analisis } \\
\text { deskriptif kuantitatif }\end{array}$ \\
\end{tabular}




\begin{tabular}{lllll}
\hline NO Jenis Data & Sifat Data & $\begin{array}{l}\text { Sumber } \\
\text { Data }\end{array}$ & Teknik Analisis Data \\
\hline & $\begin{array}{l}\text { hasil review ahli media } \\
\text { pembelajaran }\end{array}$ & & \\
$\begin{array}{l}\text { Data hasil review uji coba } \\
\text { perorangan dan data hasil } \\
\text { uji coba kelompok kecil. }\end{array}$ & $\begin{array}{l}\text { dan } \\
\text { kuantitatif }\end{array}$ & $\begin{array}{l}\text { Kuesioner/ } \\
\text { angket }\end{array}$ & $\begin{array}{l}\text { Analisis deskriptif } \\
\text { kualitatif dan analisis } \\
\text { deskriptif kuantitatif }\end{array}$ \\
\hline
\end{tabular}

\section{Hasil dan Pembahasan}

Komik pendidikan berorientasi children learning in science dikembangkan melalui empat tahapan yaitu : (1) Pengumpulan informasi, (2) Perencanaan, (3) Pengembangan produk, (4) Tahap validasi dan uji coba. Berikut adalah tahapan pengembangan yang telah dilaksanakan. Tahap pertama dari metode Borg \& Gall yaitu tahapan pengumpulan informasi. Dalam tahapan pengumpulan informasi dilakukan untuk mengetahui karakteristiksiswa di SD Negeri 1 Kesiman dan apa saja kebutuhan pembelajaran di lapangan. Tahap pengumpulan informasi ini dilakukan dengan cara studi pustaka dan studi lapangan dengan metode wawancara. 1) Studi pustaka mengenai teori yang berhubungan dengan sumber belajar bentuk komik untuk pembelajaran IPA di SD serta studi pustaka mengenai materi daur hidup hewan (metamorfosis). 2) Studi lapangan dilakukan untuk mengetahui kebutuhan dari sumber belajar di SD Negeri 1 Kesiman. Studi lapangan dilakukan dengan cara analisis tahap perkembangan siswa, analisis kurikulum yang berlaku di sekolah, dan analisis ketersediaan sumber belajar di lapangan.

Tahapan kedua yaitu tahap perencanaan dimana pada tahap perencanaan dimulai dengan penentuan KD dan indikator yang dilakukan sesuai dengan studi pustaka mengenai materi daur hidup hewan (metamorfosis) pada tema 6 muatan IPA. Tujuannya agar media pembelajaran komik pendidikan yang dikembangkan mampu membantu siswa untuk memahani materi ajar yang sesuai dengan tuntutan kompetensi dalam pembelajaran. Kemudia setelah menentukan KD dan indikator tahapan selanjutnya dari tahap perencanaan adalah desain media pembelajaran komik. Desain media pembelajaran komik pendidikan menggunakan desain dari comic strip atau komik potongan yang hanya terdiri dari 1 sampai 3 halaman dengan 1 halamannya terdiri dari 46 panel. Kemudian dilanjutkan dengan membuat story line. Pada storyline inilah dituangkan alur-alur dari cerita komik pendidikan yang dikembangkan.

Tahap ketiga yakni tahap pengembangan produk. Pada tahapan ini produk yang telah didesain dan dirancang, kemudian dikembangkan berdasarkan desain awal dan storyline yang telah dibuat. Kegiatan yang dilakukan adalah membuat desain tampilan komik pendidikan ini menggunakan menggambar manual dan aplikasi Adobe Photoshop CS6. Tahapan pembuatan produk dijabarkan sebagai berikut. (1) Tahapan penentuan panel. Pada tahapan ini yang dilakukan adalah menentukan berapa banyak panel yang akan digunakan dan penempatannya. (2) Tahapan Penggambaran karakter. Pada tahapan ini mendesain karakter atau tokoh-tokoh yang ada di dalam komik menggunakan Adobe Photoshop CS6. (3) Tahapan penempatan balon kata dan penyususnan teks. Pada tahapan ini dilakukannya penempatan balon kata serta penyusunan teks percakapan dan materi. (4) Tahap pemberian warna. Pada tahapan yang terakhir adalah pemberian warna pada komik agar terlihat menarik bagi siswa menggunakan Adobe Photoshop CS6 seperti pada Gambar 1. 

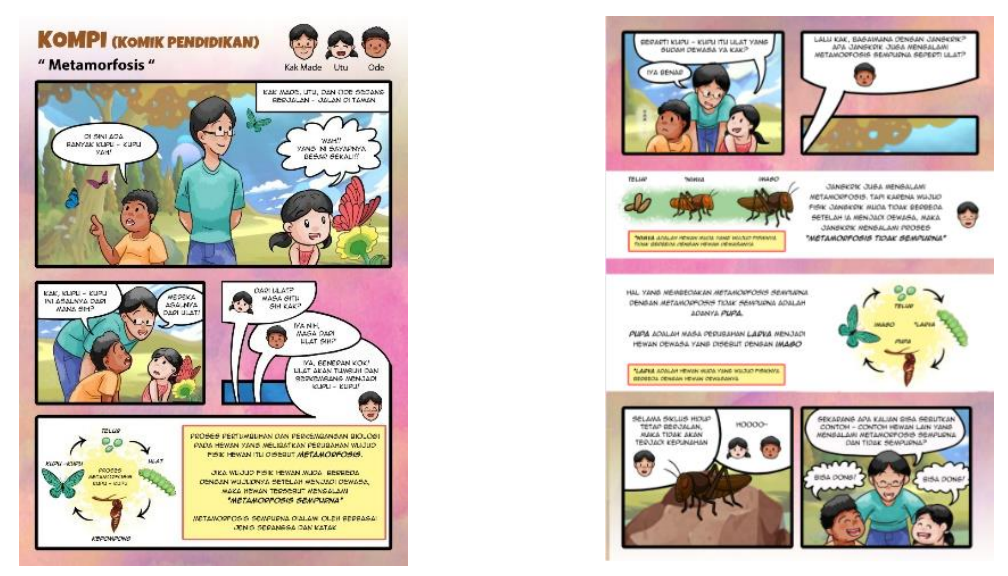

Gambar 1. Hasil dari Pengembangan Media Komik Pendidikan Berorientasi Children Learning In Science

Tahap keempat Tahap validasi dan uji coba. Media pembelajaran komik yang telah diproduksi, kemudian dievaluasi. Bentuk dari evaluasi produk komik sebagai sumber belajar IPA adalah validasi. Validasi dilakukan dalam dua tahap. Tahap I adalah validasi oleh ahli isi mata pelajaran, ahli desain dan ahli media. Melalui tahap ini diperoleh data kelayakan produk dan saran dari ahli. Saran tersebut kemudian digunakan untuk revisi produk tahap I. Hasil revisi tahap I digunakan untuk validasi ke II oleh siswa dalam uji perorangan, saran yang didapat dari uji perorangan ini digunakan untuk revisi II. Hasil dari kedua revisi tersebut digunakan untuk uji coba penggunaan oleh siswa pada uji kelompok kecil. Hasil uji coba ini berupa angket tanggapan siswa terhadap media pembelajaran IPA bentuk komik.

Hasil uji validitas dan kelayakan dari produk pengembangan media komik pendidikan menurut uji ahli ini mata pelajaran, uji ahli desain pelajaran, ujii ahli media pembelajaran, uji coba perorangan, dan uji kelompok kecil dapat dilihat pada Tabel 3.

Tabel 3.Hasil uji Validitas produk

\begin{tabular}{llll}
\hline No & Subjek Uji Coba & Hasil Validitas (\%) & Kualifikasi \\
\hline 1 & Uji Ahli Isi Mata Pelajaran & 92,3 & Sangat Baik \\
2 & Uji Ahli Desain Pembelajaran & 94,2 & Sangat Baik \\
3 & Uji Ahli Media Pembelajaran & 95,5 & Sangat Baik \\
4 & Uji Coba Perorangan & 91,7 & Sangat Baik \\
5 & Uji Coba Kelompok Kecil & 91,3 & Sangat Baik \\
\hline
\end{tabular}

Dari semua pengujian yang telah dilaksanakan kepada para ahli isi, desain, dan media pembelajaran, media komik pendidikan ini mendapatkan beberapa masukan dan saran sebagai berikut. Dari ahli isi mata pelajaran mendapat masukan untuk memperbaiki beberapa kata yang kurang baku digunakan. Kemudian dari ahli desain pembelajaran memberikan saran untuk lebih meningkatkan fasilitas atau mengakomodasi keragaman gaya belajar masing-masing siswa yang berbeda-beda. Dan terakhir dari ahli desain media pembelajaran memberikan saran agar media komik ini dibuat supaya lebih dapat memaparkan materi lebih dari 1 sub tema pada muatan IPA.

Komik pendidikan memperoleh kualifikasi sangat baik dari aspek isi mata pelajaran. Materi dalam komik telah dikembangkan dengan berpedoman pada (1) kurikulum, (2), kesesuaian gambar, (3) penggunaan kata-kata yang mudah dimengeti. Materi komik telah sesuai dengan kurikulum dan mengacu pada rumusan tujuan pembelajaran. Gambar-gambar yang digunakan dalam komik sangat mendukung kejelasan teks atau materi dalam komik. Digunakan gambar ilustrasi untuk mengkonkrektkan pesan kepada peserta didik. Pengemasan yang baik tentu akan membantu peserta dalam proses belajarnya (Kristyowati, 2018). kata-kata yang 
digunakan dalam komik adalah bahasa sederha sesuai dengan tingkat perkembangan peserta didik. Bahasa dalam komik cenderung semi formal sehingga ini akan memberikan kedekatan dengan siswa. Penerapan prinsip ini ternyata lebih baik bagi siswa ketika ia akan menerapkan pengetahuannya (Rey \& Steib, 2013).

Validitas komik dari aspek media pembelajaran berada pada kategori sangat baik. Komik telah memenuhi kaidah-kaidah media visual yang baik dengan memenuhi unsur teks, gambar, tata letak, warna, dan ukuran. Jenis teks yang digunakan dalam komik adalah jenis sans serif. Jenis teks ini sangat sesuai dengan karakteristik siswa SD. Siswa lebih memudah membaca teks jenis sans serif pada komik. Tipe huruf sans serif memiliki tebal tipis yang jelas dan biasanya dipakai pada buku teks dan surat kabar (Monica, 2010). Gambar yang digunakan dalam komik adalah gambar ilustrasi dengan berbagai warna yang menarik. Gambar merupakan kekuatan utama dalam media komik. Gambar menyajikan objek-objek yang sangat kontekstual dan dekat dengan karaksteristik anak seperti suasana lingkungan sekitar rumah, suasana persawahan, maupun kebun. Gambar merupakan salah satu wujud visual. Visual yang didesain dengan baik akan meningkatkan pemahaman dan membantu peserta didik dalam memilih, mengorganisasikan, dan mengintegrasikan informasi-informasi penting (McCrudden \& Rapp, 2017). Hasil penelitian lainnya menunjukkan bahwa peran visual mampu meningkatkan pemahaman konsep dan meningkatkan kemampuan berpikir tingkat tinggi (Armansyah et al., 2019; Raiyn \& Jamal, 2016). Warna pada komik menggunakan warnawarna yang kontras sehingga teks dan gambar menjadi semakin jelas. Disamping itu, warna yang digunakan mampu memberikan daya tarik bagi siswa. Tata letak dikhususnya untuk mendesain teks dan gambar. Teks dan gambar diletakkan secara berdekatan sehingga siswa akan terbantu memahami pesan tersebut secara utuh.

Pada aspek desain pembelajaran validitas komik adalah sangat baik. Desain pembelajaran pada komik. Komik telah dikembangkan dengan menerapkan desain pembelajaran mulai dari penyajian tujuan, pemberian petunjuk belajar, penyajian materi, dan pemberian kesimpulan. Desain pembelajaran yang dikemas dengan baik dapat membantu siswa belajar secara sistematis, terarah, dan teroganisir (Az Zafi \& Partono, 2020).

Komik yang dikembangkan dinilai sangat menarik oleh siswa berdasarkan kuesioner yang telah diberikan pada tahap uji coba perorangan dan kelompok kecil. Siswa menilai bahwa gambar-gambar yang digunakan sangat menarik, teksnya mudah dibaca, dan tentunya siswa lebih mudah memahami pesan pembelajaran melalui komik. Hasil penelitian menunjukkan bahwa unsur teks dan gambar mampu menarik perhatian dan membuat peserta didik senang (Jannah et al., 2020).

Komik yang dikembangkan dinilai valid dan layak digunakan dalam pembelajaran. Mengingat komik tersebut telah dikemas dengan baik dan menarik. Komik memiliki sebuah potensi besar jika digunakan dalam dunia pendidikan dalam mengatasi masalah kurangnya minat membaca siswa. Beberapa penelitian terdahulu juga mendukung kelayakan dari media Komik pendidikan dalam pembelajaran serta dapat meningkatkan hasil belajar siswa. Dari pengembangan dan dukungan hasil-hasil penelitian bahwa media komik pendidikan yang dikembangkan dapat dikatakan sangat layak digunakan dalam pross pembelajaran di sekolah dasar khususnya kelas IV SD. Serta dapat mengasah kemampuan guru dalam memanfaatkan kemajuan teknologi untuk memajukan pendidikan dan secara tidak langsung hal ini berdampak juga pada kemampuan guru dalam mengoperasikan media pendukung yakni laptop dan LCD projector.

\section{Simpulan}

Pengembangan media pembelajaran komik pendidikan dilakukan dengan model pengembangan Borg \& Gall dengan hasil validitas sebagai berikut. Hasil review ahli isi mata pelajaran, ahli media, dan ahli desain pembelajaran menunjukkan hasil yang sangat baik. Begitu pulan hasil uji coba perorangan dan kelompok kecil diperoleh hasil yang sangat baik Dengan ini dapat disimpulkan bahwa media pembelajaran komik valid dari 
aspek isi, media, dan desain pembelajaran serta layak digunakan dalam pembelajaran kususnya muatan IPA di sekolah dasar.

\section{Ucapan Terimakasih}

Ucapan terimaksih ditujukan kepda SD Negeri 1 Kesiman yang sudah mengizinkan penelitian di sekolah yang bersangkutan. Kepada guru kelas IV SD Negeri 1 Kesiman yang telah memberikan banyak masukan yang bermanfaat. Kepada ahi isi, ahli desain, dan ahli media pembelajaran yang telah menilai dan memberi masukan untuk penyempurnaan media yang dikembangkan. Kepada dosen pembimbing yang telah membimbing sejak awal penelitian ini. Kepada orang tua, saudara serta teman-teman yang telah memberi dukungan. Serta semua orag yang turut serta dalam pengembangan media pembelajaran komik pendidikan ini yang tidak dapat disebutkan satu per satu.

\section{Daftar Pustaka}

Agung, A. A. G. (2014). Metodologi Penelitian Pendidikan. Aditya Media Publishing.

Andriyani, F., \& Kusmariyatni, N. N. (2019). Pengaruh Media Komik Berwarna terhadap Hasil Belajar IPA Siswa. Jurnal Pedagogi Dan Pembelajaran, 2(3), 341. https://doi.org/10.23887/jp2.v2i3.19282

Armansyah, F., Sulton, S., \& Sulthoni, S. (2019). Multimedia Interaktif Sebagai Media Visualisasi Dasar-Dasar Animasi. Jurnal Kajian Teknologi Pendidikan, 2(3), 224229. https://doi.org/10.17977/um038v2i32019p224

Astiti, N. P. M., Ardana, I. K., \& Wiarta, I. W. (2017). Pengaruh Model Pembelajaran Children Learning in Science Berbasis Budaya Penyelidikan Terhadap Kompetensi Pengetahuan Ipa. Journal of Education Technology, 1(2), 86. https://doi.org/10.23887/jet.v1i2.11744

Az Zafi, A., \& Partono, P. (2020). Desain Pembelajaran sebagai Upaya Peningkatan Kualitas Pembelajaran al-Quran Hadis. MATAN: Journal of Islam and Muslim Society, 2(1), https://doi.org/https://doi.org/10.20884/1.matan.2020.2.1.2292

16-25.

Budiarti, W. N., \& Haryanto, H. (2016). Pengembangan Media Komik Untuk Meningkatkan Motivasi Belajar Dan Keterampilan Membaca Pemahaman Siswa Kelas Iv. Jurnal Prima Edukasia, 4(2), 233. https://doi.org/10.21831/jpe.v4i2.6295

Daryanto. (2013). Media Pembelajaran. Gava Media.

Jannah, I. N., Prasetiyawati, D., Hariyanti, D., \& Prasetyo, S. A. (2020). Efektivitas Penggunaan Multimedia dalam Pembelajaran IPA di SD. 4(1), 54-59.

Kristyowati, R. (2018). Lembar Kerja Peserta Didik (LKPD) IPA Sekolah Dasar Berorientasi Lingkungan. Prosiding Seminar Dan Diskusi Nasional Pendidikan Dasar 2018, 284.

Kuswanto, J., Walusfa, Y., Artikel, S., Korespondensi, A., Ratu Penghulu No, J., Sari, K., Baru, T., Raja Tim, B., Ogan Komering Ulu, K., \& Selatan, S. (2017). Pengembangan Multimedia Pembelajaran pada Mata Pelajaran Teknologi Informasi dan Komunikasi Kelas VIII. Innovative Journal of Curriculum and Educational Technology (IJCET), 6(2), 58-64. https://journal.unnes.ac.id/sju/index.php/ujet

Martina, K., Tegeh, I. M., \& Sukmana, Y. I. I. W. (2018). Pengembangan Media Strip Comic Dengan Model Addie Pada Mata Pelajaran Ipa Untuk Meningkatkan Motivasi Belajar Siswa Kelas V. Jurnal Edutech Undiksha, 6, 246-255.

McCrudden, M. T., \& Rapp, D. N. (2017). How Visual Displays Affect Cognitive Processing. Educational Psychology Review, 29(3), 623-639. https://doi.org/10.1007/s10648-015-9342-2 
Mifta, \& Nurizzati. (2017). Pembuatan komik metamorfosis kupu-kupu untuk anak sekolah dasar kelas tinggi. Jurnal IImu Informasi Perpustakaan Dan Kearsipan, 6(1), 5766. https://doi.org/https://doi.org/10.24036/8163-0934

Monica. (2010). Pengaruh Warna, Tipografi, dan Layout pada Situs. Humaniora, 1(2), 459-468.

Pramadi, I. P. W. Y., Suastra, I. W., \& Candiasa, I. M. (2013). Pengaruh Penggunaan Komik Berorientasi Kearifan Lokal Bali Terhadap Motivasi Belajar Dan Pemahaman Konsep Fisika. E-Journal Program Pascasarjana Universitas Pendidikan Ganesha, 3, 1-10.

Puspitorini, R., Prodjosantoso, A. K., Subali, B., \& Jumadi, J. (2014). Penggunaan Media Komik Dalam Pembelajaran Ipa Untuk Meningkatkan Motivasi Dan Hasil Belajar Kognitif Dan Afektif. Jurnal Cakrawala Pendidikan, 3(3), 413-420. https://doi.org/10.21831/cp.v3i3.2385

Rahayu, L. S., Sony, I., \& Anggoro, S. (2019). Materi Volume Bangun Ruang Tak Beraturan Menggunakan Model Project Based Learning. 243-256.

Raiyn, \& Jamal. (2016). The Role of Visual Learning in Improving Students' High-Order Thinking Skills. Journal of Education and Practice, 7(24), 115-121.

Rey, G. D., \& Steib, N. (2013). The personalization effect in multimedia learning: The influence of dialect. Computers in Human Behavior, 29(5), 2022-2028. https://doi.org/10.1016/j.chb.2013.04.003

Sudjana, N., \& Rivai, A. (2011). Media Pengajaran. In Media Pengajaran. Sinar Baru Algensindo.

Surya, I. G., \& Dantes, N. (2019). Pengaruh Model CLIS terhadap Hasil Belajar IPA Kelas V SD di Gugus X Kecamatan Kintamani. Jurnal Pedagogi Dan Pembelajaran, 1(1), 56. https://doi.org/10.23887/jp2.v1i1.19335

Tegeh, I. M., \& Kirna, I. M. (2010). Metodeogi Penelitian Pengembangan Pendidikan. Universitas Pendidikan Ganesha. 